\title{
Formation of Discipline Based on the Teaching of Al-Quran among the Military Personnel
}

\author{
Zahimi Zainol Abidin ${ }^{1}$, Noor Azmi Mohd Zainol ${ }^{1}$, Daud Mohamed Salleh ${ }^{1}$, Jessica Ong Hai Liaw ${ }^{1}$, \\ Ahmad Azan Ridzuan ${ }^{1} \&$ Norlaila Mazura Mohaiyadin ${ }^{1}$ \\ ${ }^{1}$ Faculty of Defence Studies and Management, National Defence University of Malaysia, \\ Sungai Besi Camp, 57000 Kuala Lumpur, Malaysia.
}

\begin{abstract}
This descriptive study will be discussing on the disciplinary problems among the army personnel, the contributing factors to the problem as well as coming up with Islamic approach solutions to the problem. This study is significant as discipline plays primary roles in building a man's character. Discipline is also synonymous with one's manners, virtue and courtesy. Several scholars have defined discipline as a mental and moral practices in ensuring one's adherence to rules and regulation for the betterment of the society. Via AlQuran, Islam has promoted discipline as the interjecting factor which leads to success in this world and hereafter. However, disciplinary problem in any organisation is still the core problem that needs to be resolved. Discipline and themilitary are synonymous and the ability to adhere to the rules that have been determined is the decisive factor which can lead to one's career excellence in the military. However, there are some military personnel who are involved in disciplinary cases which could compromise the reputation of the military. Zina (unlawful sexual relations), gambling, alcoholism are some of the criminal cases that have been committed by these personnel. It is believed that the occurrences of these cases are due to their lack of religious knowledge and practices (not performing prayers and being ignorant towards the Al-Quran), lack of parental guidance and family problems. Several steps have been taken to counter these problems as well as to curb it from further spreading such as enforcing religious classes. With that note, this paper will investigate how the principles of AlQuran can assist in the instillation of discipline as outlined in Islamic teachings among the military personnel. This study will use a qualitative method by reviewing related documents, conducting interviews and carrying out observations in order to identify the elements which contribute to this problem. Further in-depth discussion will be carried out on the current disciplinary problems, its contributive factors and resolving steps based on the principles of Al-Quran in order to instill high discipline level within the Malaysian Armed Force.
\end{abstract}

Keywords: Discipline, Malaysian Armed Forces, Al-Quran, religious practices.

\section{Introduction}

During the globalisation era, compelling level of discipline is required in determining the excellence of an organisation. In order to produce men with high level of integrity and professionalism, one would need to observe the principles of discipline. In a lament term, discipline refers to the rules of life, while to lead a disciplined life, one needs to obey the rules that are closely linked to adherence, restriction, mannerism and courtesy.

Islam teaches its followers to be disciplined in every aspects of life in order to produce honourable mannerism as Rasullah SAW, who was sent to men by Allah SWT as the messenger to improve the manners and characters of men. Rasullah SAW has decreed;

"That I was sent to perfect good character."

(HR Bukhairi, Ahmad dan Al-Hakim) 
The image of the military does not confine to immaculate uniform and complete set of armory. It needs to be fastened with high level of discipline and honourable mannerism. According to Sarah (2008), military personnel are expected to observe, adhere, respect and protect the reputation of their force as well as implementing the religious principles into their daily life. This would ensure them to be on the righteous path. However, if these disciplinary principles are not embedded within them, the probability for them to be disobedient would be most likely.

\section{The Importance of Discipline in Military}

Ahmad Shalaby (1970) claims that Prophet Muhammad SAW had been involved in 27 ghazwah (war). Prophet Muhammad had survived all the wars based on his belief and faith in Allah SWT. The Prophet and other Islam warriors had made Al-Quran as a guidance in their struggle as well as a reference to resolve conflicts. Allah had bestowed his guidance and assistance which lead to the winning of the Badar War on 17 Ramadhan Second Year of Hijrah upon witnessing Prophet Muhammad SAW's piety and devotion towards Allah, His disciples and warriors fought relentlessly and selflessly in order to spread the message of Islam (Ahmad Shalaby 1970).

The level of discipline among the disciples and the Muslim army was flawless. The correlation between discipline and success was evident within Salahudin Al-Ayubi and Muhammad Al-Fateh. Salahudin, a devout Muslim who abstained himself from material wealth was admired by his troops (Abul Al-Hasan Nadwi 1996). Due to his utmost level of discipline, he had successfully seized Palestine from the Jewish occupation. Similar achievement was achieved by Muhammad Al-Fateh whom aspired to realise Prophet Muhammad's prophecy during the expedition of opening the city of Constantinople. Al-Fateh laid his utmost faith solely in Allah SWT and his Prophet;

\section{"The city of Constantinople shall befall to the Muslims. The leader who conquered the city is the noblest leader and his troops are the noblest troops"}

[H.R. Ahmad bin Hanbal Al-Musnad 4/335]

The success of conquering the city would be impossible without high level of discipline among the leaders and his troops. The troops of Al-Fateh were chosen based on their level of faith in Allah. Military personnels who were obedient to Allah and His messenger as well as to their leaders were the pillars of Al-Fateh's success. This is evident in the following verse;

\section{"O you who believe, obey Allah, obey His messenger and the leaders among you".}

(Al-Quran 4:59)

The violation of discipline codes and failure to follow orders would bring devastating impact in a larger scale. John (1993) stated the primary reason to Russia's failure in invading and conquering Afghanistan in 1989 was due to their poor discipline. The Afghan warrior's unflinching fighting spirit, unity and faith as well as their willingness to die as martyrs for the sake of safeguarding their country were also the contributing factors to the unsuccessful conquering mission of the Russian. However, in 2003, Afghanistan failed to defend their previous triumph. Contributing factors such as failure to stay united as a nation between the people and the government, further added on by treacherous and undisciplined troops, the Americans had managed to invade Afghanistan with ease.

Among the primary disciplinary cases amongst the personnel of Malaysian army which seriously affected their fighting spirit and motivational levels are Absence without Leave, drug abuse, crime offences and suicide (Daud 2014). Identity disorder is commonly associated with the defence forces due to misconducts which would compromise the reputation of the organisation. Firearms (Weaponry perhaps?) expertise and projection of bravery that have been instilled within all military personnel were misused and misdirected. Such problems do not occur merely in Malaysia, but also amongst the Army staffs in other countries as well with cases such as 
amok and behavioral misconduct (misdemeanors perhaps?). Only with high level of discipline as the pillar which would lead to an improved character building especially within the army personnel. Without discipline, it would be difficult for an army to feel responsible in defending and protecting the religion, race and nation.

\section{Al-Quran dictates Discipline}

A study conducted by Habib \& Zetti (2011) revealed that the generation of Al-Quran is a generation who is uniquely Muslim with immaculate physical, mental, spiritual and behaviour which is fostered from one's belief and faith in Allah S.W.T. This fostered noble character is developed based on the concepts or traits of uluhiyah (acknowledgement that Allah is the only One) and rubbiyyah (acknowledgement of Allah's immense power). During the period of Rasullah SWA, the Prophet had produced eminent leaders such as Ali bin Abi Talib, 'Aisyah, Ibnu Abbad, Umar al-Khatab, Zaid bin Thabit and many others. Rasullah had trained his Muslim warriors based on the guidance provided in the Al-Quran, consequently they had successfully amplified the Islamic empire even before and after the death of Rasullah. Al-Quran teaches the men to be disciplined by adhering to Allah's commands and to refrain from His prohibitions. Allah said;

"Obey the call of your Lord before coming from God. One day that cannot be denied."

(Al -Quran, 26:47)

Prophet Muhammad was created by Allah and the Prophet had led his life with utmost discipline and adherence to regulations. Prophet Muhammad is perceived by his followers as exemplified leader. Allah said;

"Indeed in the Messenger of Allah (Muhammad SAW) you have a good example to follow for him who hopes in (the Meeting with) Allah and the Last Day and remembers Allah much"

(Al-Quran, 33:21)

Al-Quran is an absolute and complete revelation which revealed the life of the previous Prophets before the arrival of Muhmmad as well as dictating every aspects of life; aqidah (creed), syariah (Islamic law) and akhlak (morals). Akhlak (morals) originates from the Arabic term Khuluq which is defined as habit or temperament. It is also closely related to the term ethics, good character and courtesy. It is a significant human trait that enable one to differentiate between virtuous and immorality, to which, a virtuous act would be practiced whilst abandoning any immoral acts. Conceptually, the terms ethics and moral share similar definition in which both terms describe the behaviour and conducts of men from a moral perspective (Ainain 1985). Prophet Muhmmad SAW said:

“That I was only sent to complete noble characte ”.

[H.R. Ahmad bin Hanbal, Al-Musnad 4/335)

\section{Contributing Factors that Lead to the Formation of Discipline}

Zahimi (2011) in his study claimed the following as the factors which lead to the increment of disciplinary cases and reduction of discipline level among the military personnel's;

\section{- The Educating Role of Parents and Family}

Demographic factor is one of the factors that contribute to one's level of discipline. It is discovered that military personnel with disciplinary problems is caused by the lack of inculcating good values by their family members. Alamiah (2004) states that the demography of military personnel is influential in determining one's behaviour and discipline level. In addition, discipline is to be inculcated by parents, and the lack of attention in this matter would lead them to misdemeanor as they are unable to discern between good and bad.

Due to rapid change of lifestyle, the roles of parents today have been taken over by someone else to which the children are not given proper attention. Parents need to realise that they are the determinant factor which shapes the children's behaviour (Bakhtiar 1994). Motivation, discipline, closes relationship between children and 
parents as well as strong family foundation would influence one's personality, motivation level and academic achievement.

It can be postulated that family unit is a significant socialization agent. If the family unit is disbanded, it would bring a negative cognitive impact towards the children or adolescents. Unconducive household and irresponsible parents are perceived as the primary factors that cause the social problems among adolescents at present. Based on several studies on disciplinary problems among teenagers today, it were found that many of them came from broken families. It is argued that the misbehavior of these adolescents are due to impeded mental development, therefore, they are not able to reason and make rational decision, (Melson, 1992; Sheldon et al, 1985; Shoba, 2007; Wong, 1996). The source of discipline among military personnel can be traced to their family who has inculcated the value of discipline in them since young. With solid level of discipline inclusive military training, it is very unlikely the military personnel would break any disciplinary codes.

Razali (1994) affirms that parents have to play their roles responsibly in shaping theirchildren by providing them with positive nurturing within a harmonious household. As the adolescents reach their puberty age, they seek for freedom and self-identity. This caused an inner conflict within them as they feel the need to be liberated from their parents, whilst at the same time, still financially dependent onto their parents. Maslow (1954) claims the lack of care and affection is the main cause to personality disorder which involves aggressiveness and antisocial behaviours. Negative parents' behavior can cause difficulty in developing and shaping the mind of adolescents. According to Ambert (2001) and Anderson \& Sabatelli (1995), good moral values that are nurtured by parents would lead to positive result as they reach adulthood. Zahimi (2001) observed that the behaviourism of military personnel as they enter the service reflect the values and characters that have been ingrained in them by their parents, their schooling experience and friends. If they are ignorant towards the principles and practices of Islam such as inability to recite Quranic verses, not performing prayers, not observing the Ramadhan month and lack of religious knowledge throughout the first eighteen years of their life, most likely they will retain their negative behavior throughout their military service. Any misconducts caused by these personnel, not only compromise the reputation of Malaysian Armed Forces but the military would be blamed for their inability to instill good values within their personnel. There are also some families who choose to enlist their children into military services with the hope that the armed forces will be able to modify their children's disciplinary problems. Parents should perform their roles responsibly by nurturing their children with good values as stated by Allah;

"O you who believe! Protect yourselves and your families from a Fire, whose fuel is people and stones. Over it are angels, fierce and powerful. They never disobey God in anything He commands them, and they carry out whatever they are commanded"

(Al-Quran 66:6).

\section{- Religious Education Factor}

To have a religious education is a necessity in one's life as it is perceived to be the savior of men. Islam is based on the concepts of tauhid (Oneness of God), absolute justice and pre-determined regulations which connect men and the Creator (Haron 1998; Mohd 2004; Akmal 2014). Believer of God will adhere to the regulations and restrain oneself from committing vices like traduce, envy, treachery, consuming alcohol, zina (unlawful sexual relations), and hypocrisy for their fear of God's punishment onto them. Islam is the true religion that provides and dictates guidance for men in terms of muamalat (commercial and civil acts or dealings under the Islamic law), jinayat (the criminal Islamic law), munakahat (social interactions) and many other

principles Haron 1998; Mohd 2004; Akmal 2014). Therefore, it is a prime obligation for any Muslim army to equip oneself with the knowledge of Islam. 


\section{- Basic Religious Knowledge}

One needs to learn and equip oneself with religious education or knowledge since young as to minimize one's tendency to commit any wrongdoings that would incur God's wrath when they enter adulthood. One who embraces the teachings and principles of Islam would have a secure moral standing and be highly respected in the society. In fact, one's faith is not complete without the practice of moral values in one's life. It is compulsory for any Muslim to learn and discern between obligatory, prohibited, non-obligatory, disfavoured (makruh) and indifferent (mubah). Any muslim would lead their life based on pre-set principles (Fardhu Ain) by Allah. The Five Pillars of Islam are the basic knowledge and foundation for any Muslim. One is not worthy to be called as a Muslim unless one acknowledges and embraces it. It is found that the new recruitment of Malaysian Army has very little or hardly any basic knowledge of Islam and if this trend continues, it would definitely jeopardise the reputation of the Malaysian Army in the near future (Asmawati, 2003; Haron, 1988; Yusran, 2008; Zahimi, 2011)

\section{- Al- Quran Literacy}

Al- Quran contains words of guidance from Allah, in which a believer would embrace it as a guide to life. Men are incapable to re-create Al-Quran, what more to dispute its wisdom. In spite of government's effort to incorporate Al- Quran into the syllabus of primary and secondary school levels, it is revealed that this effort fails to achieve its aims and objectives (Abdul Halim, 1991; Ramli; 2000). There are some military personnel who are unable to read the Quran based on the source provided by the Military Religious Corps. Mohd Yusof (2000) said that many military personnel can be labelled as Al-Quran illiterate. Apart from that, those who could recite the verses of Al-Quran are too little. Therefore, it is unsurprising that they are not able to take Al-Quran as a reference in life, hence drives them to commit disciplinary problems due to their ignorance on the teachings of Al-Quran. They fail to recognise that the strength of Muslim military during the period of Rasullah SAW was because of their strong faith in Al-Quran.

\section{- The Organisation of Religious Activities}

The Military Religious Corps is given the responsibilities to coordinate and organise any religious activities and Islamic education in Malaysian Armed Forces. The main function of the corps as outlined by the Armed Forces Council, is to provide education and any religious services such as death and matrimony related matters to all three armed forces; Army, Navy and Air force in order to nurture the spiritual development of the forces. Zahimi (2011) argues that the role of the corps needs to be re-examined as their roles and functions have very little impact to the military personnels. This view is supported by an interview conducted with the officer in charged in 2014 who felt that the corps has failed in instilling high level of discipline among the military personnel. Due to such awareness, the corps has organised a programme; Pendidikan Islam Fardhu Ain (Fardhu Ain Islamic Education) and based on the feedback, it is evident that the level of comprehension and Islamic knowledge among the personnels have increased significantly.

\section{- The Attitude of the Military Personnel towards Religious Practices and Programs}

A person's attitude towards religion is one of the factors in shaping his disciplinary behavior. Lack of faith and endurance among the Army personnel make them vulnerable to any negative influence. A positive attitude would form when one is exposed to positive stimulants, whereas, a negative behavior would form when there is evidence of negative elements surrounding one's life. Adolescence begins from the age of 12 until 18 years old and based on this age group, there are many military personnel who are still adolescent or just entering adulthood when they were recruited by the Malaysian Army. These adolescents would suffer an emotional disturbance when they fail to adjust to new surrounding and elements of the military (Hurlock 1973). Adolescents are commonly perceived to have empty souls and lack of endurance strength.

During the process of teaching and learning, one's attitude does not only influence the process of acquiring of knowledge, also it would influence one's determination in completing a task subsequently determining the level of one's success. Attitude does not only involve one's acceptance to religion among the personnel, also it involves the leaders in the troops (Cohen, 1955; Harlen, 1996; Kozlow \& Nay, 1976; Sezali, 1997). According 
to Zahimi (2011), there are Commanding Officers who emphasizes on the involvement of its staff in any religious activities. However, there are certain teams who are ignorant towards these activities. Despite the regimented ruling which provides zero opportunity for any personnel to disobey the system, there are some services who disregarded these activities. Attendance and participation to these activities are solely depending on the awareness of the personnel, hence the aims and objectives of these programs are not achieved optimistically. The formation of one's discipline is determined by one's attitude and this attitude depends on one's reaction and acceptance towards the phenomena that happen in his life.

\section{Discussion and Implications of Findings}

Based on the studies by researchers and supports from various interviews, and internal reviews, several matters have been identified as the primary causes that contribute to the disciplinary problems among the Army personnel. These factors comprise of family, religious education, Al-Quran literacy, organisation of religious activities and the attitude of the personnel towards religion. Therefore, these problems need to be wisely solved by the superior leaders.

As a Muslim armed force, they are not only responsible to protect the sovereignty of the nation but also they have a missionary role to play in order to spread the Islamic dakwah (preach). They can be an exemplary role model for any non-Muslim army personnel as they could ignite their interest to learn about Islam.

The Military Religious Corps also needs to re-examine their roles and responsibilities in ensuring that their staff are well-equipped to impart any theoretical and practical knowledge to the Army personnel. They need to apply any attractive methods to motivate the personnel to increase their Islamic knowledge. Conventional teaching methods to be conducted in mosques are no longer sufficient as they need to upgrade their teaching approach with the aid of modern teaching tools. Apart from that, the recruitment of religious teachers or officers need to be re-assessed. It is a challenging task for any religious officers to deal with problematic army personnel, therefore, the selection of these staffs cannot solely depend on their academic qualification.

Apart from the selection of the members of the Military Religious Corps, the recruitment of military personnel also needs to be re-evaluated. Physical and academic factors are insufficient to produce Quranicreading generation among the Armed Forces. Their religious knowledge needs to be assessed and be taken into consideration before being recruited into the force.

This study is conducted to identify the contributing factors to the rampant disciplinary problems that occur in the Army. Therefore, a further quantitative study needs to be conducted in order to get some comprehensive insights in relation to this issue as well as to measure this problem statistically. With more studies being conducted in regards to this issue, ergo, more data are collected and can be used to find effective solutions to the problem.

\section{Conclusion}

Based on the discussion above, it is evident that the behaviour of Army personnel can be modified according to the principles of Al-Quran in order to help them to survive the challenging era of post-modernism. Preparation, planning as well as continuous and sincere efforts in providing support, knowledge and effective religious activities are some of the ways that can be implemented to instil high level of disciplinary values among the Army personnel. Any form of misconducts, carelessness and mistakes if not caught early, would be a lost cause.

\section{References}

[1] Al-Quran.

[2] Abdul Halim El-Muhammady (1991). Pendidikan Islam: Falsafah disiplin dan Peranan Pendidik. Kuala Lumpur: Dewan Pustaka Salam.

[3] Abul Al-Hasan Nadwi, Arnold, (1996). Preaching of Islam. London: Stanley Lane Saladin (Salahuddin al-Ayubi).

[4] Ahmad Shalaby( 1970). History of Muslim Education. Beirut: Dar-al Kashshaf. 
[5] Ainain, A.K. A. (1985). Falsafah al-Tarbiyah fi al-Quran al-Karim. Dar al-Fikr al-`Arabiy.

Akmal, M. Z. (2014). Asas Pengetahuan Agama Islam. Kuala Lumpur: Al Hidayah Publisher.

[6] Ambert, A.M., (2001). The effect of children on parent (2nd Ed.). New York: The Haworth Press.

[7] Anderson, S.A., \& Sabatelli, R.M. (1995). Family interaction: A multigenerational developmental perspective. Boston: Allyn and Bacon.

[8] Asmawati, S. (2003). Pemantapan Komponen Akhlak dalam Pendidikan Islam bagi menangani era globalisasi. Tesis Sarjana (tidak diterbitkan). Serdang: Universiti Putra Malaysia.

[9] Bakhtiar, M. (1994). Ponteng Satu Pendekatan Secara Kaunseling. Jurnal Bimbingan dan Kaunseling. 10 (92), 165-176.

[10] Cohen, A. (1955). Deliquent Boys:The Culture of the Gang. New York: Glienco Illianos.

[11]Daud, M.J. (2014). Morel dan pengaruhnya terhadap motivasi dan komitmen di kalangan anggota Tentera Darat Malaysia. Tesis Doktor Falsafah (tidak diterbitkan). Batu Pahat: Universiti Tun Hussien Onn Malaysia.

[12] Hurlock, E.B., (1973). Adolescence Development. New York: Mc Graw-Hill Book Co.

[13] Harlen, W. (1996). The teaching of science in primary school. London: David Fulton.

[14] Haron, D. (1988). Manusia dan Islam. Shah Alam: Penerbitan Hizbi.

[15] Hoover, J.E (1965). Core Isuues in Policing. London: Pearson Education Ltd.

[16] John, R. (1992). Imperialisme: globalisasi, kerajaan dan peperangan. International Socialism Journal, 93(4), 26-28

[17] Kozlow, M. J. \& Nay, M. A. (1976). An approach to measuring scientific attitudes.Jurnal of Science Education. 60(2): $\underline{147-172 .}$ https://doi.org/10.1002/sce.3730600203

[18] Maslow, A.H. (1970). Motivation and Personality (2nd Ed.). New York: Harper \& Row.

[19] Melson, G.F., (1992). Keluarga dan Persekitaran Perspektif Ekosistem. Kuala Lumpur: Dewan Bahasa dan Pustaka.

[20] Ramli, K. (2000). Rasuah Polis: Satu kes kajian. Tesis Sarjana (tidak diterbitkan). Universiti Kebangsaan Malaysia: Selangor.

[21] Razali, C. M. (1994). Remaja Lepak Semua Pihak Perlu Campur Tangan dalam Dewan Siswa: Kuala Lumpur.

[22] Sarah, S. G. (2008). The Influence of Islam on AIDS Prevention among Senegalese University Students. AIDS Education and Prevention. Philadelphia: The Guilford Press.

[23] Sezali, D. (1997). Langkah Menangani Gejala Sosial. Jurnal Akademik. 30(2), 71-74.

[24] Sheldon, G., Eleanor,T. \& Erica, G. (1985). Study Questions Gene Influence on Male Homosexuality. New York: Simon and Schuster publication.

[25] Shoba, K. (2007). Faktor- faktor yang mempengaruhi kemerosotan disiplin di kalangan pelajar sekolah menengah di Johor. Tesis Sarjana (Tidak diterbitkan). Skudai: Universiti Teknologi Malaysia.

[26] Wong K. S. (1996). Fenomena Budaya Lepak. Jurnal Akademik. 45(7), 75-78.

[27] Yusran, A. (2008). Strategi perkembangan pendidikan agama Islam pada sekolah umum. Jurnal Kependidikan. 1(1) 6272.

[28]Zahimi, Z.A. (2011). Hubungan Disiplin Anggota Tentera Darat di Lembah Klang dengan faktor Agama. Tesis Sarjana (Tidak diterbitkan). Sintok: Universiti Utara Malaysia.

[29]Zetty Nurzuliana, R. \& Ab. Halim, T. (2014). Melahirkan generasi al-Quran melalui kurikulum pendidikan integrasi dan holistik Jabatan Agama Islam Selangor. Jurnal Penyelidikan dan Inovasi . 1 (2), 74 - 83. 